\title{
Protective effects of hydrogen sulfide inhalation on oxidative stress in rats with cotton smoke inhalation-induced lung injury
}

\author{
ZHI-HAI HAN $^{1 *}$, YI JIANG ${ }^{2 *}$, YUN-YOU DUAN ${ }^{1}$, XIAO-YANG WANG ${ }^{1}$, YAN HUANG $^{1}$ and TING-ZHENG FANG $^{1}$ \\ ${ }^{1}$ Pulmonary and Critical Care Medicine of PLA Navy General Hospital, Beijing 100048; \\ ${ }^{2}$ Political Department Clinic of Shenyang Military Area Command, Shenyang, Liaoning 110032, P.R. China
}

Received May 22, 2014; Accepted December 17, 2014

DOI: $10.3892 /$ etm.2015.2482

\begin{abstract}
The aim of the present study was to investigate the mechanism by which hydrogen sulfide $\left(\mathrm{H}_{2} \mathrm{~S}\right)$ inhalation protects against oxidative stress in rats with cotton smoke inhalation-induced lung injury. A total of 24 male Sprague-Dawley rats were separated randomly into four groups, which included the control, $\mathrm{H}_{2} \mathrm{~S}$, smoke and smoke $+\mathrm{H}_{2} \mathrm{~S}$ groups. A rat model of cotton smoke inhalation-induced lung injury was established following inhalation of $30 \%$ oxygen for $6 \mathrm{~h}$. In addition, $\mathrm{H}_{2} \mathrm{~S}(80 \mathrm{ppm})$ was inhaled by the rats in the $\mathrm{H}_{2} \mathrm{~S}$ and smoke $+\mathrm{H}_{2} \mathrm{~S}$ groups for $6 \mathrm{~h}$ following smoke or sham-smoke inhalation. Enzyme-linked immunosorbent assays were performed to measure various indices in the rat lung homogenate, while the levels of nuclear factor (NF)- $\mathrm{Bp} 65$ in the lung tissue of the rats were determined and semiquantitatively analyzed using immunohistochemistry. In addition, quantitative fluorescence polymerase chain reaction was employed to detect the mRNA expression of inducible nitric oxide synthase (iNOS) in the rat lung tissue. The concentrations of malondialdehyde (MDA), nitric oxide (NO), inducible iNOS and NF- $\mathrm{Bp} 65$, as well as the sum-integrated optical density of NF- $\kappa$ Bp65 and the relative mRNA expression of iNOS, in the rat lung tissue from the smoke $+\mathrm{H}_{2} \mathrm{~S}$ group were significantly lower when compared with the smoke group. The concentrations of MDA, NO, iNOS and $\mathrm{NF}-\kappa \mathrm{Bp} 65$ in the $\mathrm{H}_{2} \mathrm{~S}$ group were comparable to that of the control group. Therefore, inhalation of $80 \mathrm{ppm}_{2} \mathrm{~S}$ may reduce iNOS mRNA transcription and the production of iNOS and NO in rats by inhibiting NF- $\mathrm{Np} 65$ activation, subsequently decreasing oxidative stress and cotton smoke inhalation-induced lung injury.
\end{abstract}

Correspondence to: Dr Zhi-Hai Han, Pulmonary and Critical Care Medicine of PLA Navy General Hospital, 6 Fucheng Road, Beijing 100048, P.R. China

E-mail: zhihaihancn@163.com

\section{*Contributed equally}

Key words: acute lung injury, smoke inhalation injury, oxidative stress, hydrogen sulfide

\section{Introduction}

Smoke inhalation injury (SII) mainly affects the airways and lung parenchyma, causing severe toxic pneumonitis or pulmonary edema. These conditions may rapidly develop into acute lung injury (ALI) and acute respiratory distress syndrome, which increase the morbidity and mortality rates in patients (1). Oxidative stress is an important SII mechanism, as high-temperature smoke contains a high concentration of strong oxidants. The resultant inflammatory response, if uncontrolled, causes abundant inflammatory cell accumulation in the lungs, producing excessive reactive oxygen species (ROS) and inducing oxidative stress injury.

Previous studies have shown that hydrogen sulfide $\left(\mathrm{H}_{2} \mathrm{~S}\right)$ exerts antioxidative (2) and antifibrotic effects, and plays important roles in vasodilation (3-6) and the regulation of the inflammatory response (7), endocrine and reproductive systems (8). Inhalation of $80 \mathrm{ppm}_{2} \mathrm{~S}$ for $6 \mathrm{~h}$ has been demonstrated to suppress the systemic inflammatory response and enhance survival rates in mouse models of endotoxin-induced ALI $(9,10)$. In addition, inhalation of $\mathrm{H}_{2} \mathrm{~S}$ has been shown to reduce lung damage in mouse models of hyperventilation-induced ALI by inhibiting pulmonary inflammation and alveolar epithelial cell apoptosis (11). In a previous study, increased oxidative stress was observed in rats with cotton smoke inhalation-induced lung injury (12). The aim of the present study was to observe the effect of $80 \mathrm{ppm}_{2} \mathrm{~S}$ inhalation for $6 \mathrm{~h}$ on oxidative stress in rats with SII.

\section{Materials and methods}

Animals and grouping. A total of 24 healthy, clean, adult male Sprague-Dawley rats (weight, 150-250 g) were provided by the Laboratory Animal Center of the Academy of Military Medical Sciences [SCXK-(Military)-2012-0004] and fed in the Laboratory Animal Center of the Navy General Hospital [SCXK-(Military)-2012-0012]. The rats were randomly divided into four groups, including the control, $\mathrm{H}_{2} \mathrm{~S}$, smoke and smoke $+\mathrm{H}_{2} \mathrm{~S}$ groups ( $\mathrm{n}=6$ in each), in accordance with the regulations for the administration of affairs concerning experimental animals (13). This study was conducted in strict accordance with the recommendations of the Guide for the Care and Use of Laboratory Animals of the National Institutes of Health (14). Furthermore, the animal use protocol was 
reviewed and approved by the Institutional Animal Care and Use Committee of the Second Military Medical University (Beijing, China).

Establishment of the SII model and $\mathrm{H}_{2} \mathrm{~S}$ inhalation. A rat model of SII was established by placing two randomly selected rats from the smoke and smoke $+\mathrm{H}_{2} \mathrm{~S}$ groups into a smoke chamber. The smoke was generated by sealing $2 \mathrm{~g}$ cotton (Sunny Cotton Company, Xinjiang, China) in a soldering machine (Fudi HT-B, Hongtai Hardware and Electric Equipment Company, Guangzhou, China) at $300^{\circ} \mathrm{C}$, which was subsequently channeled into the chamber containing the rats. The rats were left to inhale the smoke for $2 \mathrm{~min}$ or until red/purple spots developed on the plantar skin, with symptoms of restlessness, tachypnea, mouth breathing, Kussmaul breathing and stridor (15-17). The smoke chamber was opened to allow the rats to breathe fresh air for $7 \mathrm{~min}$ before the chamber was resealed. This procedure was repeated three to five times, until the rats remained unconscious after $7 \mathrm{~min}$ of air inhalation. The rats in the control and $\mathrm{H}_{2} \mathrm{~S}$ groups underwent the same procedure, but without smoke inhalation. Following the smoke or sham smoke inhalation, rats in the $\mathrm{H}_{2} \mathrm{~S}$ and smoke $+\mathrm{H}_{2} \mathrm{~S}$ groups inhaled $80 \mathrm{ppm}_{2} \mathrm{~S}+30 \%$ oxygen for $6 \mathrm{~h}$, while rats in the control and smoke groups inhaled $30 \%$ oxygen for $6 \mathrm{~h}$. The rats had free access to food and water.

Enzyme-linked immunosorbent assay (ELISA). Rats were euthanized with an intraperitoneal injection of pentobarbital sodium. A double-antibody sandwich avidin-biotin-peroxidase complex-ELISA (Jiamay Biotech Co. Ltd., Beijing, China) was performed to determine the levels of nitric oxide (NO), inducible nitric oxide synthase (iNOS) and nuclear factor (NF)- $\kappa$ Bp65 in the lower right lung homogenate. In addition, the concentration of malondialdehyde (MDA) was measured using colorimetry.

Immunohistochemistry (IHC) of $N F-\kappa B p 65$. The right middle lobes of the rat lungs were fixed in $4 \%$ paraformaldehyde for $72 \mathrm{~h}$, embedded in paraffin, sectioned at $3 \mu \mathrm{m}$ and preheated at $60-65^{\circ} \mathrm{C}$ for $4 \mathrm{~h}$. This was followed by deparaffinization, rehydration, washing in phosphate-buffered saline, high temperature antigen retrieval, endogenous peroxidase blocking in $3 \% \mathrm{H}_{2} \mathrm{O}_{2}$ and normal goat serum blocking. The slides were incubated with $50 \mu$ l anti-NF-кBp65 primary antibody (ab16502; Abcam, Cambridge, UK) at 1:200 dilution overnight $\left(4^{\circ} \mathrm{C}\right)$, and a secondary horseradish peroxidase-conjugated anti-mouse/rabbit IgG antibody (KIT-5020; Maixin-Bio, Fuzhou, China) for $20 \mathrm{~min}$ at room temperature. The slides were subsequently stained with diaminobenzidine and counterstained with hematoxylin. For the negative control, the primary antibody was replaced with serum. Positive expression was observed as yellow or brown staining. Image-Pro Plus 6.0 software (Media Cybernetics, Inc., Rockville, MD, USA) was used for semiquantitative analysis by randomly selecting five high-power fields (magnification, x1,000) from each slide. Image-Pro Plus 6.0 software was used to calculate the sum-integrated optical density (IOD) of the mean density, and the IOD of the positive staining in each field, as well as the mean value of these parameters.

Quantitative fluorescence-polymerase chain reaction $(q F-P C R)$. Forward and reverse primers for iNOS were synthesized by Jiamay Biotech Co. Ltd. as follows: 5'-ACACCGATTCCACTCAACTA-3' and 5'-ACCACC TGTTAGTTCAAGCC-3', respectively. The amplified products were $159 \mathrm{bp}$ in length and $\beta$-actin was used as an internal reference gene (CW0918; CWbio Co., Ltd., Beijing, China). Total RNA was extracted using an Ultrapure RNA Kit (CW0581; CWbio Co., Ltd.) and analyzed (5 $\mu \mathrm{l})$ with $1 \%$ agarose gel electrophoresis. The total RNA was reverse transcribed with a HiFi-MMLV-cDNA First-Strand cDNA Synthesis kit (CW0744; CWbio Co., Ltd.) and amplified using an UltraSYBR Mixture with ROX (CW0956; CWbio Co., Ltd.) under the following conditions: $95^{\circ} \mathrm{C}$ for $10 \mathrm{~min}, 40$ cycles of $95^{\circ} \mathrm{C}$ for $15 \mathrm{sec}$ and $60^{\circ} \mathrm{C}$ for $60 \mathrm{sec}$. qF-PCR was performed with a LightCycler ${ }^{\circledR} 480$ II PCR system (Roche Diagnostics, Basel, Switzerland), and the $2^{-\Delta \Delta \mathrm{Ct}}$ method was employed to analyze the relative changes in gene expression.

Statistical analysis. Data were analyzed with SPSS 18.0 software (SPSS, Inc., Chicago, IL, USA). Measurement data are presented as the mean \pm standard deviation, and comparisons were performed using one-way analysis of variance. Comparisons between groups were performed using Fisher's least significant difference test. $\mathrm{P}<0.05$ was considered to indicate a statistically significant difference.

\section{Results}

ELISA. Significantly higher concentrations of MDA, NO, iNOS and NF- $\mathrm{NBp} 65$ were observed in the rat lung homogenate from the smoke group, as compared with those in the control or smoke $+\mathrm{H}_{2} \mathrm{~S}$ groups $(\mathrm{P}<0.001)$. Furthermore, the $\mathrm{H}_{2} \mathrm{~S}$ group exhibited a higher concentration of iNOS than the control group (Table I). The levels of all the measured indicators were lower in the $\mathrm{H}_{2} \mathrm{~S}$ group when compared with those in the smoke group.

Rat body weight and relative $m R N A$ expression of $i N O S$. The mean rat body weight was $186.68 \pm 28.79 \mathrm{~g}$ and was comparable between the groups; thus, body weight was determined to have no effect on the results $(\mathrm{P}>0.05)$. The relative mRNA expression of iNOS was significantly higher in the smoke, smoke $+\mathrm{H}_{2} \mathrm{~S}$ and $\mathrm{H}_{2} \mathrm{~S}$ groups when compared with the control group $(\mathrm{P}<0.01)$; however, the levels were markedly lower in the smoke $+\mathrm{H}_{2} \mathrm{~S}$ and $\mathrm{H}_{2} \mathrm{~S}$ groups when compared with the smoke group $(\mathrm{P}<0.001$; Table II).

IHC of $N F-\kappa B p 65$. IHC results showing NF- $\kappa B p 65$ expression in the rat lungs are presented in Fig. 1. The sum-IOD of NF-кBp65 expression was higher in the smoke group when compared with the control group $(\mathrm{P}<0.001)$. However, in the smoke $+\mathrm{H}_{2} \mathrm{~S}$ and $\mathrm{H}_{2} \mathrm{~S}$ groups, the sum-IOD was lower when compared with the smoke group $(\mathrm{P}<0.01)$, but higher when compared with the control group $(\mathrm{P}<0.001)$. The mean density values of $\mathrm{NF}-\kappa \mathrm{Bp} 65$ expression in the rat lungs were comparable in the smoke, smoke $+\mathrm{H}_{2} \mathrm{~S}$ and $\mathrm{H}_{2} \mathrm{~S}$ groups, which were all lower than the value observed in the control group $(\mathrm{P}<0.01$; Table II).

\section{Discussion}

The complex composition of smoke determines the complex SII pathogenesis, in which oxidative stress is important (18). 
Table I. Concentrations of indicators in the rat lung tissue.

\begin{tabular}{lcccc}
\hline Group & MDA $(\mathrm{nmol} / \mathrm{ml})$ & NO $(\mu \mathrm{M} / \mathrm{ml})$ & iNOS $(\mathrm{pg} / \mathrm{ml})$ & $\mathrm{NF}-\kappa \mathrm{Bp} 65(\mathrm{pg} / \mathrm{ml})$ \\
\hline Control & $161.24 \pm 15.68^{\mathrm{a}}$ & $85.25 \pm 10.07^{\mathrm{a}}$ & $320.11 \pm 30.91^{\mathrm{a}}$ & $7636.77 \pm 535.48^{\mathrm{a}}$ \\
$\mathrm{H}_{2} \mathrm{~S}$ & $188.29 \pm 20.44^{\mathrm{a}}$ & $78.75 \pm 6.61^{\mathrm{a}}$ & $394.11 \pm 34.95^{\mathrm{ab}}$ & $9543.63 \pm 755.25^{\mathrm{a}}$ \\
Smoke & $332.00 \pm 52.23^{\mathrm{b}}$ & $179.00 \pm 16.04^{\mathrm{b}}$ & $603.44 \pm 50.67^{\mathrm{b}}$ & $13803.19 \pm 2196.37^{\mathrm{b}}$ \\
Smoke $+\mathrm{H}_{2} \mathrm{~S}$ & $240.38 \pm 24.26^{\mathrm{ab}}$ & $93.09 \pm 5.33^{\mathrm{a}}$ & $406.33 \pm 52.45^{\mathrm{ab}}$ & $8123.51 \pm 2095.33^{\mathrm{ab}}$ \\
F-value & 34.120 & 123.124 & 46.967 & 18.729 \\
P-value & $<0.001$ & $<0.001$ & $<0.001$ & $<0.001$ \\
\hline
\end{tabular}

Results are expressed as the mean \pm standard deviation $(\mathrm{n}=6) .{ }^{\mathrm{a}} \mathrm{P}<0.05$, vs. smoke group; ${ }^{\mathrm{b}} \mathrm{P}<0.05$, vs. control group (LSD test). MDA, malondialdehyde; NO, nitric oxide; iNOS, inducible nitric oxide synthase; NF- $\kappa$ Bp65, nuclear factor- $\kappa$ Bp65; LSD, Fisher's least significant difference.

Table II. Results of immunohistochemistry in rat lung tissue.

\begin{tabular}{lccrc}
\hline Group & iNOS mRNA & p65 Density (mean) & p65 IOD (sum) & Weight (g) \\
\hline Control & $0.07 \pm 0.03^{\mathrm{a}}$ & $0.244 \pm 0.016^{\mathrm{a}}$ & $9275.25 \pm 1219.39^{\mathrm{a}}$ & $182.13 \pm 14.29$ \\
$\mathrm{H}_{2} \mathrm{~S}$ & $0.26 \pm 0.05^{\mathrm{ab}}$ & $0.218 \pm 0.005^{\mathrm{b}}$ & $22536.16 \pm 3107.68^{\mathrm{ab}}$ & $200.43 \pm 23.23$ \\
Smoke & $2.20 \pm 0.21^{\mathrm{b}}$ & $0.219 \pm 0.009^{\mathrm{b}}$ & $32782.06 \pm 4826.13^{\mathrm{b}}$ & $195.42 \pm 47.38$ \\
Smoke $+\mathrm{H}_{2} \mathrm{~S}$ & $1.04 \pm 0.24^{\mathrm{ab}}$ & $0.218 \pm 0.010^{\mathrm{b}}$ & $25668.15 \pm 2420.81^{\mathrm{ab}}$ & $168.75 \pm 9.80$ \\
F-value & 221.670 & 8.814 & 57.700 & 1.576 \\
P-value & $<0.001$ & 0.001 & $<0.001$ & 0.226 \\
\hline
\end{tabular}

Results are expressed as the mean \pm standard deviation $(\mathrm{n}=6) .{ }^{\mathrm{a}} \mathrm{P}<0.05$, vs. smoke group; ${ }^{\mathrm{b}} \mathrm{P}<0.05$, vs. control group (LSD test). iNOS, inducible nitric oxide synthase; IOD, integrated optical density; LSD, Fisher's least significant difference.

A

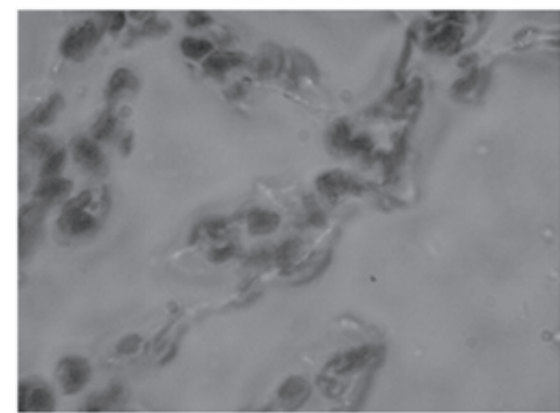

C

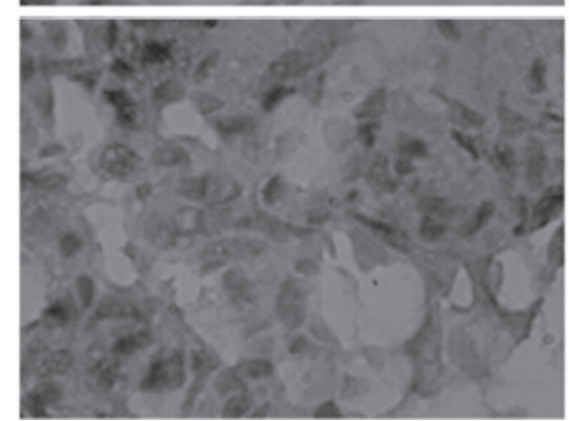

B

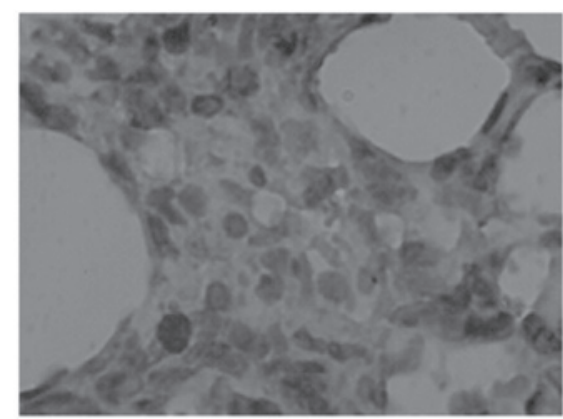

D

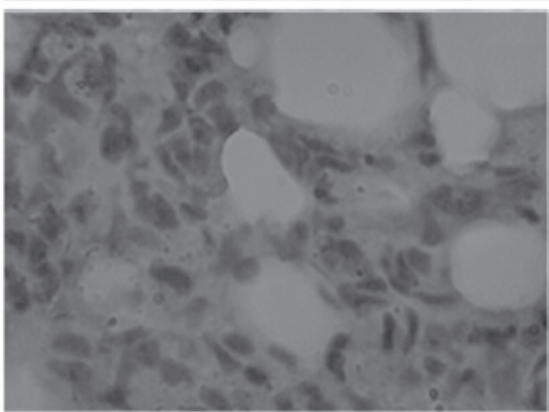

Figure 1. Histopathological observations of NF- $\mathrm{kBp} 65$ expression in the lung tissues of the (A) air, (B) $\mathrm{H}_{2} \mathrm{~S}$, (C) smoke and (D) smoke $+\mathrm{H}_{2} \mathrm{~S}$ groups (6 h) using immunohistochemistry (hematoxylin and eosin; magnification, $\mathrm{x} 1,000$ ). NF, nuclear factor; $\mathrm{H}_{2} \mathrm{~S}$, hydrogen sulfide.

Smoke inhalation can stimulate lung macrophages, neutrophils, vascular endothelial and smooth muscle cells to release abundant cytokines, including tumor necrosis factor (TNF)- $\alpha$, interleukin (IL)-1 $\beta,-6$ and -8 , which activate NF- $\kappa$ B. Following
$\mathrm{NF}-\kappa \mathrm{B}$ decomposition in the cytoplasm, active fragments of $\mathrm{NF}-\kappa \mathrm{Bp} 65$ are translocated to the nucleus to promote downstream iNOS gene transcription, enhancing the synthesis of iNOS. Arginine is subsequently metabolized, generating large 
amounts of NO that react with the superoxide free radical to synthesize peroxynitrite, leading to lipid peroxidation in the cell membrane (19). Simultaneously, NO, nitrous oxide, disulfur monoxide and other oxidizing particles in smoke are strong oxidants and stimulate granulocytes to release large quantities of oxyradicals. In addition, oxygen therapy following hypoxia increases the production of oxyradicals, which results in lipid peroxidation, membrane destruction and the activation of inflammatory mediator synthesis. Subsequently, energy metabolism is affected, causing protein denaturation and dysfunction. These factors enhance alveolar-capillary permeability, leading to exudation of the blood component into the alveolar space and pulmonary edema. Moreover, SII-induced ROS causes excessive NO synthesis, which results in vascular leakage, failure of hypoxic pulmonary vasoconstriction and an increase in the production of cytotoxic reactive nitrogen species (RNS), which further aggravate pulmonary injury (20-22). A previous study confirmed that cotton smoke inhalation for $6 \mathrm{~h}$ in rats induced typical lung injury (12). The present study showed the concentration and sum-IODs of $\mathrm{NF}-\kappa \mathrm{Bp} 65$, and the relative mRNA expression and concentration of iNOS and NO were increased in the rat lung tissue after $6 \mathrm{~h}$ of smoke inhalation. In addition, there was an increase in MDA, a peroxide produced in the reaction of free radicals and polyunsaturated fatty acids in the cell membranes, indicating an intensified oxidative stress response, lipid peroxidation and tissue injury.

Early treatment for SII following smoke inhalation is crucial. With regard to the pathogenesis of SII, interrupting oxidative stress pathways and decreasing downstream products by inhibiting $\mathrm{NF}-\kappa \mathrm{B}$ activation may theoretically ameliorate lung injury. A previous study demonstrated that continuous intravenous infusion of arginine vasopressin at a low dose can suppress the excessive generation of NO by iNOS, significantly reducing lung injury induced by burning and smoke inhalation (23).

$\mathrm{H}_{2} \mathrm{~S}$ is a harmful gas, commonly associated with the smell of rotten eggs, and has recently emerged as the third gaseous signaling molecule in addition to NO and CO $(24,25)$. Animal experiments have confirmed that intravenous infusion of $\mathrm{NaHS}$ or $\mathrm{H}_{2} \mathrm{~S}$ inhalation has antioxidative, anti-inflammatory and antiapoptotic effects in animal models of various types of lung injury $(2,9,10,26)$. However, the effects of $\mathrm{H}_{2} \mathrm{~S}$ inhalation on SII have not yet been investigated. In macrophages activated in vitro by lipopolysaccharide, $\mathrm{H}_{2} \mathrm{~S}$ can inhibit the activation of the NF- $\kappa \mathrm{B}$ signaling pathway, reduce NO production and exert an antioxidative effect (27). Therefore, the aim of the present study was to investigate the effects of $\mathrm{H}_{2} \mathrm{~S}$ inhalation on SII.

The present study revealed that inhalation of $80 \mathrm{ppm}$ $\mathrm{H}_{2} \mathrm{~S}$ for $6 \mathrm{~h}$ immediately after smoke inhalation markedly reduced rat lung injury. This reduction in injury was characterized by decreases in the concentration and sum-IOD of NF- $\mathrm{NBp} 65$, relative mRNA expression of iNOS and concentrations of iNOS, NO and MDA in the rat lung tissue, indicating that $\mathrm{H}_{2} \mathrm{~S}$ inhalation may reduce iNOS mRNA transcription, and iNOS and NO production, by inhibiting $\mathrm{NF}-\kappa \mathrm{Bp} 65$ activation. Subsequently, oxidative stress and cotton smoke inhalation-induced lung injury were reduced. The mean density of NF- $\mathrm{KBp} 65$ in the rat lungs may not be used as an indicator, since it represents the depth of positive IHC staining intensity, but not the total quantity of positive staining.

In the $\mathrm{H}_{2} \mathrm{~S}$ group, the concentrations of MDA, NO and $\mathrm{NF}-\kappa \mathrm{Bp} 65$ were comparable to those in the control group. However, the iNOS concentration, relative mRNA expression of iNOS and the sum-IOD of NF- $\kappa$ Bp65 were higher in the $\mathrm{H}_{2} \mathrm{~S}$ group compared with the control group, suggesting that inhalation of $80 \mathrm{ppm} \mathrm{H}_{2} \mathrm{~S}$ for $6 \mathrm{~h}$ caused no damage to the rats, but may activate NF- $\mathrm{NBp} 65$ signaling pathways to increase iNOS synthesis, which correlated with the negative feedback.

Recently, research into the effects of $\mathrm{H}_{2} \mathrm{~S}$ in vivo has been increasing. Different cell types or stimulations may lead to opposite results in terms of the effects of $\mathrm{H}_{2} \mathrm{~S}$ on $\mathrm{NF}-\kappa \mathrm{B}$ signaling pathways (28). For example, $\mathrm{H}_{2} \mathrm{~S}$ amplifies the IL-1 $\beta$-activated $\mathrm{NF}-\kappa \mathrm{B}$ signaling pathway, increases iNOS expression and NO production in rat vascular smooth muscle cells (29). In addition, $\mathrm{H}_{2} \mathrm{~S}$ activates the NF- $\kappa \mathrm{B}$ signaling pathway to increase the production of proinflammatory cytokines in human monocytes pretreated with interferon- $\gamma$ (30). However, $\mathrm{H}_{2} \mathrm{~S}$ inhibits the activation of the NF- $\mathrm{NB}$ signaling pathway to reduce iNOS expression in lipopolysaccharide-activated macrophages (27) or microgliacytes (31). NF- $\kappa \mathrm{B}$ is a nuclear transcription factor that maintains cell sensitivity to oxidative stress, and TNF- $\alpha$, IL- $1 \beta$ and $\mathrm{NO}$ can activate the signaling cascade of the $\mathrm{NF}-\kappa \mathrm{B}$ pathway. This pathway is influenced by numerous factors, including the status of potential sites sensitive to oxidative stress, ROS and RNS, selectivity of signaling pathways and cell types, which may affect the process of oxidative stress reactions (32). Inhalation of strong oxidant $\mathrm{H}_{2} \mathrm{~S}$ disturbs the redox balance in vivo and enhances reduction reactions, which activates the $\mathrm{NF}-\kappa \mathrm{B}$ signaling pathway, increases iNOS synthesis and produces NO against the reducing property of $\mathrm{H}_{2} \mathrm{~S}$ to complete the negative feedback loop, without evident injury in rats. However, smoke inhalation increases the oxidizing reactions, which activates the NF- $\mathrm{BB}$ signaling pathway, elevates iNOS expression and NO synthesis, causing an increase in oxidative stress that cannot be regulated by the antioxidant system (33). Therefore, $\mathrm{H}_{2} \mathrm{~S}$ inhalation provides a negative feedback system, inhibiting the activation of the NF- $\mathrm{NB}$ signaling pathway and reducing iNOS expression and $\mathrm{NO}$ synthesis, which subsequently decreases lung injury in rats. $\mathrm{H}_{2} \mathrm{~S}$ regulates $\mathrm{NF}-\kappa \mathrm{B}$ activity via the extracellular signal-regulated kinase signaling pathway $(29,30)$, p38-mitogen-activated protein kinase signaling pathway (31), heme oxygenase-1 and heat shock protein 70 (27). A previous study investigating the mechanisms of $\mathrm{H}_{2} \mathrm{~S}$ (34) revealed that $\mathrm{H}_{2} \mathrm{~S}$-mediated sulfhydration (the binding of $\mathrm{H}_{2} \mathrm{~S}$ to active-site cysteine residues of target proteins to induce protein sulfhydration and post-translational modification) may be central to the $\mathrm{H}_{2} \mathrm{~S}$ mechanism.

The present study expands the application of $\mathrm{H}_{2} \mathrm{~S}$ inhalation. Moreover, strong reductant $\mathrm{H}_{2} \mathrm{~S}$ in airways can directly neutralize oxidants, including the superoxide anion, hydrogen peroxide, superoxide nitrogen and hypochlorous acid $(35,36)$, to protect the cell membrane against free radical-induced injury. $\mathrm{H}_{2} \mathrm{~S}$ inhalation is a convenient treatment for SII; however, further investigation is required. In the present study, $\mathrm{H}_{2} \mathrm{~S}$ inhalation was applied for only $6 \mathrm{~h}$ and the long-term effects require further study. $\mathrm{H}_{2} \mathrm{~S}$ can activate ATP-sensitive potassium channels to dilate blood vessels (6), regulate Fas/Fas ligand 
death receptor pathways to reduce apoptosis, and inhibit neurogenic inflammation and the co-interaction of the three gaseous signaling molecules (37); these mechanisms may play roles in the treatment of SII. However, further confirmation is required with regard to the mechanisms underlying the effects of $\mathrm{H}_{2} \mathrm{~S}$ in SII.

In conclusion, inhalation of $80 \mathrm{ppm}_{2} \mathrm{~S}$ reduces iNOS mRNA transcription and iNOS and NO production by inhibiting NF- $\kappa$ Bp65 activation, which subsequently decreases oxidative stress and cotton smoke inhalation-induced lung injury.

\section{Acknowledgements}

This study was funded by the Research Project of the 'Twelfth Five-year Plan' for Medical Science Development of PLA (no. CWS11J180).

\section{References}

1. Ballard-Croft C, Sumpter LR, Broaddus R, Alexander J, Wang D and Zwischenberger JB: Ovine smoke/burn ARDS model: a new ventilator-controlled smoke delivery system. J Surg Res 164: e155-e162, 2010.

2. Esechie A, Kiss L, Olah G, Horváth EM, Hawkins H, Szabo C and Traber DL: Protective effect of hydrogen sulfide in a murine model of acute lung injury induced by combined burn and smoke inhalation. Clin Sci (Lond) 115: 91-97, 2008.

3. Papapetropoulos A, Pyriochou A, Altaany Z, et al: Hydrogen sulfide is an endogenous stimulator of angiogenesis. Proc Nat Acad Sci USA 106: 21972-21977, 2009.

4. Szabó C and Papapetropoulos A: Hydrogen sulphide and angiogenesis: mechanisms and applications. Br J Pharmacol 164: 853-865, 2011.

5. Yang $\mathrm{G}, \mathrm{Wu} \mathrm{L}$, Jiang $\mathrm{B}$, et al: $\mathrm{H}_{2} \mathrm{~S}$ as a physiologic vasorelaxant: hypertension in mice with deletion of cystathionine gamma-lyase. Science 322: 587-590, 2008.

6. Muzaffar S, Jeremy JY, Sparatore A, Del Soldato P, Angelini GD and Shukla N: $\mathrm{H}_{2} \mathrm{~S}$-donating sildenafil (ACS6) inhibits superoxide formation and gp91phox expression in arterial endothelial cells: role of protein kinases A and G. Br J Pharmacol 155: 984-994, 2008.

7. Li PC, Chen WC, Chang LC and Lin SC: Substance P acts via the neurokinin receptor 1 to elicit bronchoconstriction, oxidative stress, and upregulated ICAM-1 expression after oil smoke exposure. Am J Physiol Lung Cell Mol Physiol 294: L912-L920, 2008.

8. Zhu XY, Gu H and Ni X: Hydrogen sulfide in the endocrine and reproductive systems. Expert Rev Clin Pharmacol 4: 75-82, 2011.

9. Tokuda K, Kida K, Marutani E, et al: Inhaled hydrogen sulfide prevents endotoxin-induced systemic inflammation and improves survival by altering sulfide metabolism in mice. Antioxid Redox Signal 17: 11-21, 2012.

10. Faller S, Zimmermann KK, Strosing KM, et al: Inhaled hydrogen sulfide protects against lipopolysaccharide-induced acute lung injury in mice. Med Gas Res 2: 26, 2012.

11. Faller S, Ryter SW, Choi AM, Loop T, Schmidt R and Hoetzel A: Inhaled hydrogen sulfide protects against ventilator-induced lung injury. Anesthesiology 113: 104-115, 2010.

12. Zhang $Y$, Han Z, Duan Y, et al: The influence of inhalation $H 2 S$ lung in rats. Jie Fang Jun Yi Xue Yuan Xue Bao 35: 1241-1244, 2014

13. McPherson C: Regulation of animal care and research? NIH's opinion. J Animal Sci 51: 492-496, 1980.

14. National Research Council (US) Committee for the Update of the Guide for the Care and Use of Laboratory Animals. Guide for the Care and Use of Laboratory Animals, 8th edition. National Academies Press (US), Washington (DC), 2011.

15. Lee HM, Greeley GH, Herndon DN, Sinha M, Luxon BA and Englander EW: A rat model of smoke inhalation injury: influence of combustion smoke on gene expression in the brain. Toxicol Appl Pharmacol 208: 255-265, 2005
16. Huang PS, Tang GJ, Chen $\mathrm{CH}$ and Kou YR: Whole-body moderate hypothermia confers protection from wood smoke-induced acute lung injury in rats: the therapeutic window. Crit Care Med 34: 1160-1167, 2006.

17. Zou YY, Lu J, Poon DJ, Kaur C, Cao Q, Teo AL and Ling EA: Combustion smoke exposure induces up-regulated expression of vascular endothelial growth factor, aquaporin 4, nitric oxide synthases and vascular permeability in the retina of adult rats. Neuroscience 160: 698-709, 2009.

18. Rehberg S, Maybauer MO, Enkhbaatar P, Maybauer DM, Yamamoto Y and Traber DL: Pathophysiology, management and treatment of smoke inhalation injury. Expert Rev Respir Med 3: 283-297, 2009.

19. Enkhbaatar P and Traber DL: Pathophysiology of acute lung injury in combined burn and smoke inhalation injury. Clin Sci (Lond) 107: 137-143, 2004

20. Cox RA, Jacob S, Oliveras G, et al: Pulmonary expression of nitric oxide synthase isoforms in sheep with smoke inhalation and burn injury. Exp Lung Res 35: 104-118, 2009.

21. Westphal M, Enkhbaatar P, Schmalstieg FC, et al: Neuronal nitric oxide synthase inhibition attenuates cardiopulmonary dysfunctions after combined burn and smoke inhalation injury in sheep. Crit Care Med 36: 1196-1204, 2008.

22. Rehberg S, Maybauer MO, Maybauer DM, Traber LD, Enkhbaatar P and Traber DL: The role of nitric oxide and reactive nitrogen species in experimental ARDS. Front Biosci (Schol Ed) 2: $18-29,2010$.

23. Westphal M, Rehberg S, Maybauer MO, et al: Cardiopulmonary effects of low-dose arginine vasopressin in ovine acute lung injury. Crit Care Med 39: 357-363, 2011.

24. Calvert JW: The summer of hydrogen sulfide: highlights from two international conferences. Med Gas Res 3: 5, 2013.

25. Gadalla MM and Snyder SH: Hydrogen sulfide as a gasotransmitter. J Neurochem 113: 14-26, 2010.

26. Liu WL, Liu ZW, Li TS, Wang C and Zhao B: Hydrogen sulfide donor regulates alveolar epithelial cell apoptosis in rats with acute lung injury. Chin Med J (Engl) 126: 494-499, 2013.

27. Oh GS, Pae HO, Lee BS, et al: Hydrogen sulfide inhibits nitric oxide production and nuclear factor-kappaB via heme oxygenase-1 expression in RAW264.7 macrophages stimulated with lipopolysaccharide. Free Radic Biol Med 41: 106-119, 2006.

28. Wagner F, Asfar P, Calzia E, Radermacher P and Szabó C: Bench-to-bedside review: Hydrogen sulfide - the third gaseous transmitter: applications for critical care. Crit Care 13: 213, 2009.

29. Jeong SO, Pae HO, Oh GS, et al: Hydrogen sulfide potentiates interleukin-1beta-induced nitric oxide production via enhancement of extracellular signal-regulated kinase activation in rat vascular smooth muscle cells. Biochem Biophys Res Commun 345: 938-944, 2006

30. Zhi L, Ang AD, Zhang H, Moore PK and Bhatia M: Hydrogen sulfide induces the synthesis of proinflammatory cytokines in human monocyte cell line U937 via the ERK-NF-kappaB pathway. J Leukoc Biol 81: 1322-1332, 2007.

31. Hu LF, Wong PT, Moore PK and Bian JS: Hydrogen sulfide attenuates lipopolysaccharide-induced inflammation by inhibition of p38 mitogen-activated protein kinase in microglia. J Neurochem 100: 1121-1128, 2007.

32. Janssen-Heininger YM, Poynter ME and Baeuerle PA: Recent advances towards understanding redox mechanisms in the activation of nuclear factor kappaB. Free Radic Biol Med 28: 1317-1327, 2000.

33. LaLonde C, Nayak U,Hennigan J and Demling R: Plasma catalase and glutathione levels are decreased in response to inhalation injury. J Burn Care Rehabil 18: 515-519, 1997.

34. Paul BD and Snyder SH: $\mathrm{H}_{2} \mathrm{~S}$ signalling through protein sulfhydration and beyond. Nat Rev Mol Cell Biol 13: 499-507, 2012.

35. Whiteman M, Armstrong JS, Chu SH, et al: The novel neuromodulator hydrogen sulfide: an endogenous peroxynitrite 'scavenger'? J Neurochem 90: 765-768, 2004.

36. Whiteman M, Cheung NS, Zhu YZ, et al: Hydrogen sulphide: a novel inhibitor of hypochlorous acid-mediated oxidative damage in the brain? Biochem Biophys Res Commun 326: 794-798, 2005.

37. Arai M,YoshiokaS,Nishimura RandOkudaK:FAS/FASL-mediated cell death in the bovine endometrium. Anim Reprod Sci 151: 97-104, 2014. 